\title{
Glycoprotein $\mathrm{E}^{\text {rns }}$ of Pestiviruses Induces Apoptosis in Lymphocytes of Several Species
}

\author{
CHRISTIANNE J. M. BRUSCHKE,* MARCEL M. HULST, ROB J. M. MOORMANN, \\ PIET A. VAN RIJN, JAN T. VAN OIRSCHOT \\ Department of Mammalian Virology, Institute for Animal Science and \\ Health (ID-DLO), 8200 AB Lelystad, The Netherlands
}

Received 13 February 1997/Accepted 3 June 1997

\begin{abstract}
Classical swine fever virus and bovine virus diarrhea virus are members of the genus pestivirus, which belongs to the family of the Flaviviridae. Recently, envelope glycoprotein $\mathbf{E}^{r n s}$ was identified as an RNase. RNases can express different biological actions. They have been shown to be neurotoxic, antihelminthic, and immunosuppressive. We studied the immunosuppressive properties of $E^{r n s}$ in vitro. The glycoprotein totally inhibited concanavalin A-induced proliferation of porcine, bovine, ovine, and human lymphocytes. We then studied the direct cytotoxic effects of $\mathbf{E}^{r n s}$ on lymphocytes and epithelial cells in protein synthesis assays. $E^{r n s}$ strongly inhibited the protein synthesis of lymphocytes of different species, without cell membrane damage. This suggested an apoptotic process, and indeed apoptosis of lymphocytes was detected after incubation with $\mathbf{E}^{r n s}$. Pestivirus infections are characterized by leukopenia and immunosuppression. Our results suggest that $E^{\text {rns }}$ plays an important role in the pathogenesis of pestiviruses.
\end{abstract}

The family of the Flaviviridae consists of three genera: flavivirus, pestivirus, and hepatitis $\mathrm{C}$ virus. Flaviviridae are small, enveloped viruses with diameters of 40 to $60 \mathrm{~nm}$. The genome is a single positive-strand RNA molecule of 12.5 to $16.5 \mathrm{~kb}$. The genomes of flaviviruses and hepatitis $\mathrm{C}$ virus encode two envelope-associated glycoproteins: E1 and E2 (9, 22). In addition to E1 and E2, pestiviruses contain an extra envelope glycoprotein, which has been designated $\mathrm{E}^{\text {rns }}(3,24)$. The viral function of glycoprotein $\mathrm{E}^{r n s}$, which is secreted in considerable amounts into the extracellular environment (18), is not yet clear. Recently, $E^{r n s}$ was identified as an RNase $(10,19)$. Classical functions of RNases are the processing of RNA in gene expression and the digestion of dietary RNA. RNases can also exert cytotoxic activities and can be involved in, e.g., antitumor and immunomodulatory processes $(4,16,23)$. Since pestivirus infections induce leukopenia and immunosuppression $(2,5,15$, $21,25)$, we investigated whether $\mathrm{E}^{r n s}$ of CSFV, which belongs to the pestivirus genus, has immunomodulatory effects in vitro.

\section{MATERIALS AND METHODS}

Abbreviations. BVDV, bovine virus diarrhea virus; $\mathrm{cf}$, control fraction; CSFV, classical swine fever virus; EBTr, embryonic bovine tracheal; EMEM, Earle's minimal essential medium; MAb, monoclonal antibody; ncpm, netto counts per minute; PBS, phosphate-buffered saline; PBMC, peripheral blood mononuclear cells; SK, swine kidney; ELISA, enzyme-linked immunosorbent assay.

$\mathbf{E}^{r n s}$ production and purification. Purified $\mathrm{E}^{r n s}$ was prepared as described previously (10). Briefly, Spodoptera frugiperda cells were infected with recombinant baculovirus expressing glycoprotein $\mathrm{E}^{r n s}$ of CSFV strain $\mathrm{C}(1)$. Infected cells were incubated for $96 \mathrm{~h}$ and then lysed in buffer containing $30 \mathrm{mM}$ Tris- $\mathrm{HCl}(\mathrm{pH}$ 7.5)-10 mM $\mathrm{MgCl}_{2}-1 \%$ Nonidet P-40. The lysed cultures were centrifuged to remove cell debris, and the supernatant was stored at $-20^{\circ} \mathrm{C}$. $\mathrm{E}^{r n s}$ was purified by immunoaffinity chromatography with MAb C5, directed against $\mathrm{E}^{\text {rns }}$ of CSFV strain $C$. The concentrations of protein in the fractions containing RNase activity were determined by extrapolation of the absorption at $280 \mathrm{~nm}$ on a bovine serum albumin standard curve. RNase-specific activity was assayed as described previously (10) and expressed as $A_{260}$ units per minute per milligram. The characteristics of the $E^{r n s}$ protein, produced in insect cells, were described by Hulst et al. (10). Briefly, the recombinant protein reacted with MAb C5 and was shown by radioimmunoprecipitation to be, like native $\mathrm{E}^{\text {rns }}$, a doublet of 42 to $46 \mathrm{kDa}$. Its

* Corresponding author. Mailing address: ID-DLO, P. O. Box 65, 8200 AB Lelystad, The Netherlands. Phone: 31.320.238220. Fax: 31.320.238050. E-mail: C.J.M.Bruschke@ID.DLO.NL. mobility was similar to that of $\mathrm{E}^{\text {rns }}$ precipitated from SK6 cells infected with CSFV strain Brescia. The purity of the recombinant protein was, as judged by sodium dodecyl sulfate-polyacrylamide gel electrophoresis, more than $90 \%$. The RNase activity was comparable to that of native $E^{\text {rns }}$ (19), indicating that the biological activity of $\mathrm{E}^{r n s}$ produced in insect cells is indistinguishable from that of native $\mathrm{E}^{\text {rns }}$

Control fractions were prepared from cells infected with wild-type baculovirus (cf1) and from cells infected with recombinant baculovirus expressing glycoprotein E2 of BVDV strain 4800 (cf2). The control lysates were chromatographed over column material similar to that used for the $\mathrm{E}^{\text {rns }}$ lysates.

Hybridoma cells producing MAb C5 were kindly provided by G. Wensvoort, and ascites fluid containing MAb C5 was produced as described by Wensvoort et al. (26).

Isolation of lymphocytes and the lymphocyte proliferation assay. Blood from specific-pathogen-free animals housed in isolation units and from humans was used for isolation of lymphocytes. From each species, the same animal or person was blood sampled for each successive experiment. Blood $(10 \mathrm{ml})$ was collected in heparin-coated tubes, diluted 1:1 in PBS, layered onto $5 \mathrm{ml}$ of Ficoll-Paque (Pharmacia Biotech), and centrifuged for $20 \mathrm{~min}$ at $20^{\circ} \mathrm{C}$. Human and porcine blood, ovine blood, and bovine blood were centrifuged at $500 \times g, 900 \times g$, and $1,400 \times g$. PBMC at the interface were collected, resuspended in $10 \mathrm{ml}$ of PBS, and washed twice. They were counted with a microcell counter (F-800; Sysmex) and suspended at a concentration of $4 \times 10^{6}$ cells per ml in RPMI containing $10 \%$ fetal calf serum, $0.5 \%$ antibiotic cocktail, and $5 \times 10^{-5} \mathrm{M} 2$-mercaptoethanol. The fetal calf serum was BVDV and BVDV antibody negative. The antibiotic cocktail consisted of 10,000 IU of penicillin, $11,250 \mu \mathrm{g}$ of streptomycin, $10,000 \mu \mathrm{g}$ of kanamycin, and 5,000 IU of nystatin per $\mathrm{ml}$.

Each culture of the lymphocyte proliferation assays was set up in triplicate, and the assays were performed at least twice. To each well of round-bottom microtiter plates containing $25 \mu \mathrm{l}$ of cell suspension $\left(10^{5} \mathrm{PBMC}\right), 25 \mu \mathrm{l}$ of a dilution of $\mathrm{E}^{\text {rns }}$, a similar dilution of $\mathrm{cf} 1$ or $\mathrm{cf} 2$, or cell culture medium was added. The plates were incubated for $1 \mathrm{~h}$ at $37^{\circ} \mathrm{C}$ in a $5 \% \mathrm{CO}_{2}$ humidified atmosphere. Then, $50 \mu \mathrm{l}$ of concanavalin A (type IV-S; Sigma) in RPMI was added to a final concentration of $5 \mu \mathrm{g} / \mathrm{per} \mathrm{ml}$. The plates were cultured for $72 \mathrm{~h}$ at $37^{\circ} \mathrm{C}$ in a $5 \%$ $\mathrm{CO}_{2}$ humidified atmosphere and then pulsed with $0.4 \mu \mathrm{Ci}$ of $\left[{ }^{3} \mathrm{H}\right]$ thymidine in 10 $\mu \mathrm{l}$ of RPMI per well. After 16 additional $\mathrm{h}$, the cells were harvested with an automatic 96-well harvester (Tomtec) onto glass fiber filters. Filters were dried for $1 \mathrm{~h}$ at $60^{\circ} \mathrm{C}$, and radioactivity was measured in a liquid scintillation counter (1450 Microbeta Plus; Wallac). The results were expressed as mean ncpm of the different assays, where ncpm is counts per minute of the triplicate stimulated cultures minus the mean counts per minute of the nonstimulated cultures.

To confirm the specificity of the inhibition by $\mathrm{E}^{\text {rns }}$, a blocking assay with $\mathrm{MAb}$ $\mathrm{C} 5$, which neutralizes virus infectivity, was performed. $\mathrm{E}^{\text {rns }}$ and MAb C5 were incubated for $1 \mathrm{~h}$ at $37^{\circ} \mathrm{C}$ in a humidified atmosphere before being used in the lymphocyte proliferation assay. An antibovine herpesvirus type 1 MAb, MAb 41, was used as a control.

Cell viability. Cell viability after the concanavalin A induced-lymphocyte proliferation was determined with nigrosine staining. Aliquots of cells were mixed with an equal volume of $0.2 \%$ nigrosine in PBS. Tests were performed in triplicate, and the percentages of viable cells were determined microscopically. 


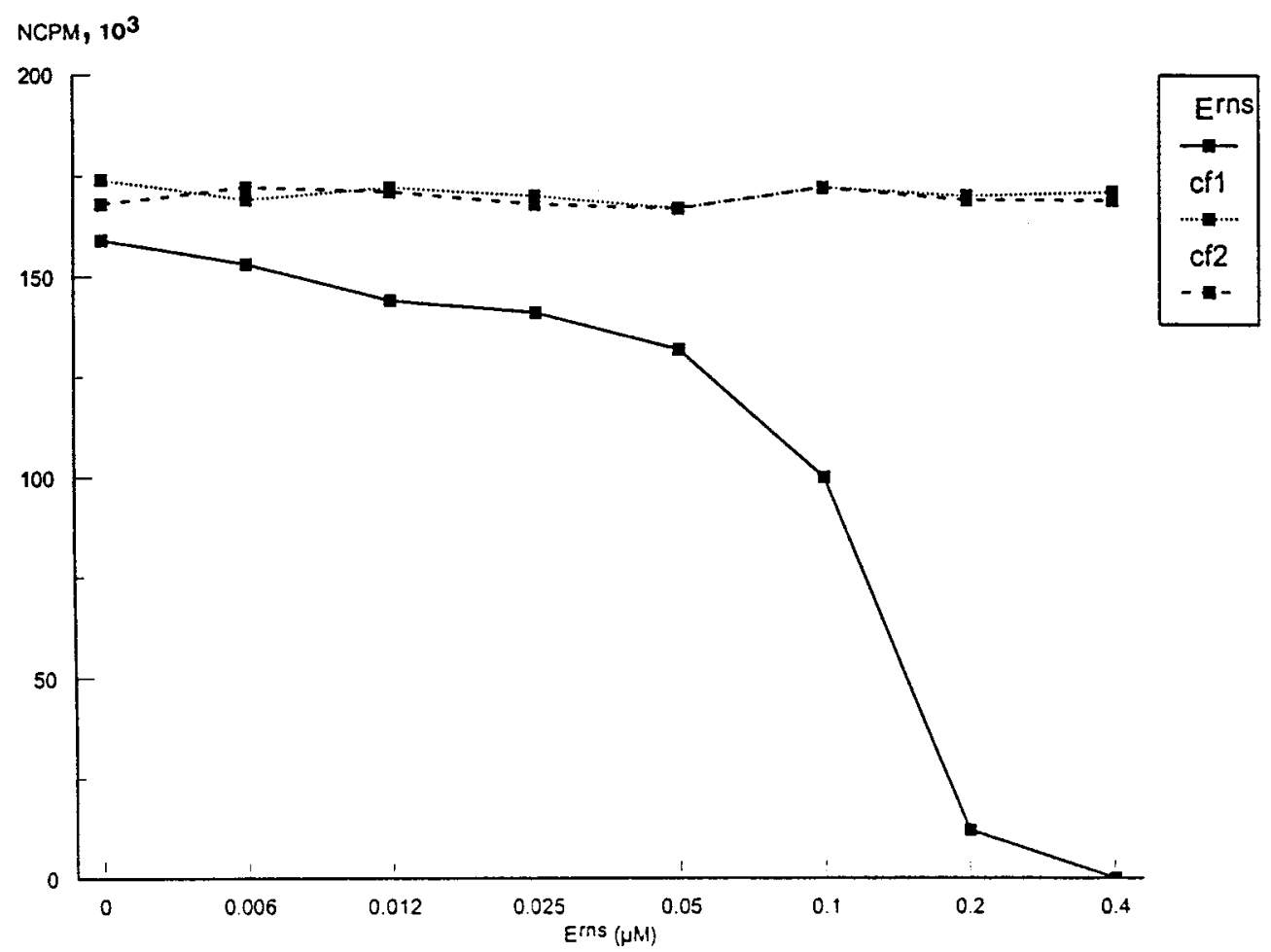

FIG. 1. The effect of immunoaffinity-purified $\mathrm{E}^{r n s}$ on concanavalin-induced proliferation of bovine lymphocytes. Dilutions of $\mathrm{E}^{\text {rns }}$ were based on the RNase activities of the fractions. From the control fractions, similar dilutions were used. Results are ncpm (i.e., counts per minute of the stimulated cultures - counts per minute of the unstimulated control cultures). Values are the averages of triplicate samples and have standard errors of less than $3 \%$.

Protein synthesis assaying. Inhibition of protein synthesis was used to assay the direct cytotoxic action of $\mathrm{E}^{r n s}$ (12). PBMC were isolated as described above, washed twice, and resuspended in leucine-free RPMI, without fetal calf serum and antibiotic cocktail, at a concentration of $2 \times 10^{6}$ cells per ml. To each well of a round-bottom microtiter plate containing $50 \mu \mathrm{l}$ of cell suspension $\left(10^{5}\right.$ PBMC), $50 \mu \mathrm{l}$ of dilutions of $\mathrm{E}^{r n s}$, similar dilutions of $\mathrm{cf} 2$, or leucine-free RPMI was added. The plates were incubated in a $5 \% \mathrm{CO}_{2}$ humidified atmosphere for 1 to $24 \mathrm{~h}$, and then $10 \mu \mathrm{l}$ of RPMI containing $0.4 \mu \mathrm{Ci}$ of $\left[{ }^{3} \mathrm{H}\right]$ leucine was added. Incubation was continued for $1 \mathrm{~h}$. The cells were harvested on DEAE filters with an automatic 96-well harvester (Tomtec). The filters were dried for $1 \mathrm{~h}$ at $60^{\circ} \mathrm{C}$, and radioactivity was measured in a liquid scintillation counter (Wallac 1450; microbeta plus). Tests were performed in duplicate.

The inhibition of the protein synthesis of EBTr and SK6 (13) by $\mathrm{E}^{\text {rns }}$ was also studied. These adherent cell types were separately cultured in $165-\mathrm{cm}^{2}$ cell culture flasks (Costar), EMEM, 10\% normal calf serum, and $0.5 \%$ antibiotic cocktail. The semicontinuous EBTr cells were originally isolated from bovine embryonic trachea in our laboratory and are used routinely. The normal calf serum was collected from specific-pathogen-free calves and was BVDV and BVDV antibody free. For the protein synthesis assay, the adherent cells were trypsinized, washed in cell culture medium, and resuspended and $5 \times 10^{6}$ cells per well were dispersed in 96-well flat-bottom microtiter plates. After $24 \mathrm{~h}$ at $37^{\circ} \mathrm{C}$, and with $5 \% \mathrm{CO}_{2}$ in regular cell culture medium, the attached cells were washed twice with leucine-free EMEM. To each well, $100 \mu \mathrm{l}$ of $0.4 \mu \mathrm{M} \mathrm{E}^{r n s}$, a similar dilution of $\mathrm{cf} 2$, or leucine-free EMEM was added. The plates were incubated at $37^{\circ} \mathrm{C}$ in a $5 \% \mathrm{CO}_{2}$ humidified atmosphere. After a defined incubation time, $10 \mu \mathrm{l}$ of PBS containing $0.4 \mu \mathrm{Ci}$ of $\left[{ }^{3} \mathrm{H}\right]$ leucine was added and the incubation was continued for $2 \mathrm{~h}$. Then, the cells were washed, trypsinized, and harvested on DEAE filters. The filters were dried for $1 \mathrm{~h}$ at $60^{\circ} \mathrm{C}$ and counted in a liquid scintillation counter (1450 Microbeta Plus; Wallac). The degree of protein synthesis after incubation of the cells with $\mathrm{E}^{\text {rns }}$ or the control fractions is expressed as a percentage of the protein synthesis of the cells in leucine-free cell culture medium.

Detection of apoptosis. Apoptosis of bovine lymphocytes was determined by the cell death detection ELISA (Boehringer Mannheim [catalog no. 1544 675]), which is based on the specific detection of mono- and oligonucleosomes in the cytoplasmic fraction of apoptotic cells. The apoptosis in $100 \mu \mathrm{l}$ of cell suspension $\left(10^{5} \mathrm{PBMC}\right)$ was determined after $8 \mathrm{~h}$ of incubation with $0.4 \mu \mathrm{M} \mathrm{E}^{\text {rns }}$, a similar dilution of cf2, or RPMI 1640. Similarly, apoptosis of EBTr cells was measured, except that these cells were trypsinized, because they were attached to flatbottom microtiter plates. The results are expressed as the enrichment factor, which represents the enrichment of mono- and oligonucleosomes in the apoptotic cells and is the quotient of the average absorbance of the test sample and the average absorbance of an untreated sample.

\section{RESULTS}

Immunosuppressive effect of $\mathbf{E}^{\text {rns }}$. We determined the immunosuppressive effect of pestivirus envelope glycoprotein $\mathrm{E}^{r n s}$ in vitro. Immunoaffinity-purified $\mathrm{E}^{r n s}$ was found to have a strongly inhibitory effect on the concanavalin A-induced proliferation of bovine lymphocytes. Incubation of the lymphocytes with a concentration of $0.4 \mu \mathrm{M} \mathrm{E}^{\text {rns }}$ completely inhibited $\left[{ }^{3} \mathrm{H}\right]$ thymidine incorporation, and even $0.01 \mu \mathrm{M} \mathrm{E}^{\text {rns }}$ resulted in a slight but significant inhibition.

The specificity of the immunosuppressive effect on lymphocyte proliferation was confirmed in two different ways. To exclude the possibility that contaminants in the purified $\mathrm{E}^{\text {rns }}$ fraction caused the inhibitory effect, cf1 and cf 2 were tested in dilutions similar to that used for $\mathrm{E}^{r n s}$ in the lymphocyte proliferation assays and did not inhibit lymphocyte proliferation (Fig. 1). Additionally, blocking assays were performed with MAb C5, which is neutralizing and is directed against $\mathrm{E}^{\text {rns }}$ of CSFV strain C. The immunosuppressive effect of $\mathrm{E}^{\text {rns }}$ could be blocked partially by MAb $\mathrm{C} 5$. Incubation of $0.2 \mu \mathrm{M} \mathrm{E}^{\text {rns }}$ with MAb C5 $(0.4 \mathrm{mg} / \mathrm{ml})$ before addition to the lymphocytes resulted in an increase in proliferation of from 1 to $35 \%$ of the maximum proliferation. Incubation of $E^{r n s}$ with antibovine herpesvirus type $1 \mathrm{MAb} 41(0.5 \mathrm{mg} / \mathrm{ml})$ did not result in an increase in lymphocyte proliferation. These results of the lymphocyte proliferation assays show that $\mathrm{E}^{r n s}$ is immunosuppressive for bovine lymphocytes in vitro.

The immunosuppressive effect of $\mathrm{E}^{r n s}$ was then studied in proliferation assays with human, porcine, and ovine lympho- 
$\%$ viable cells

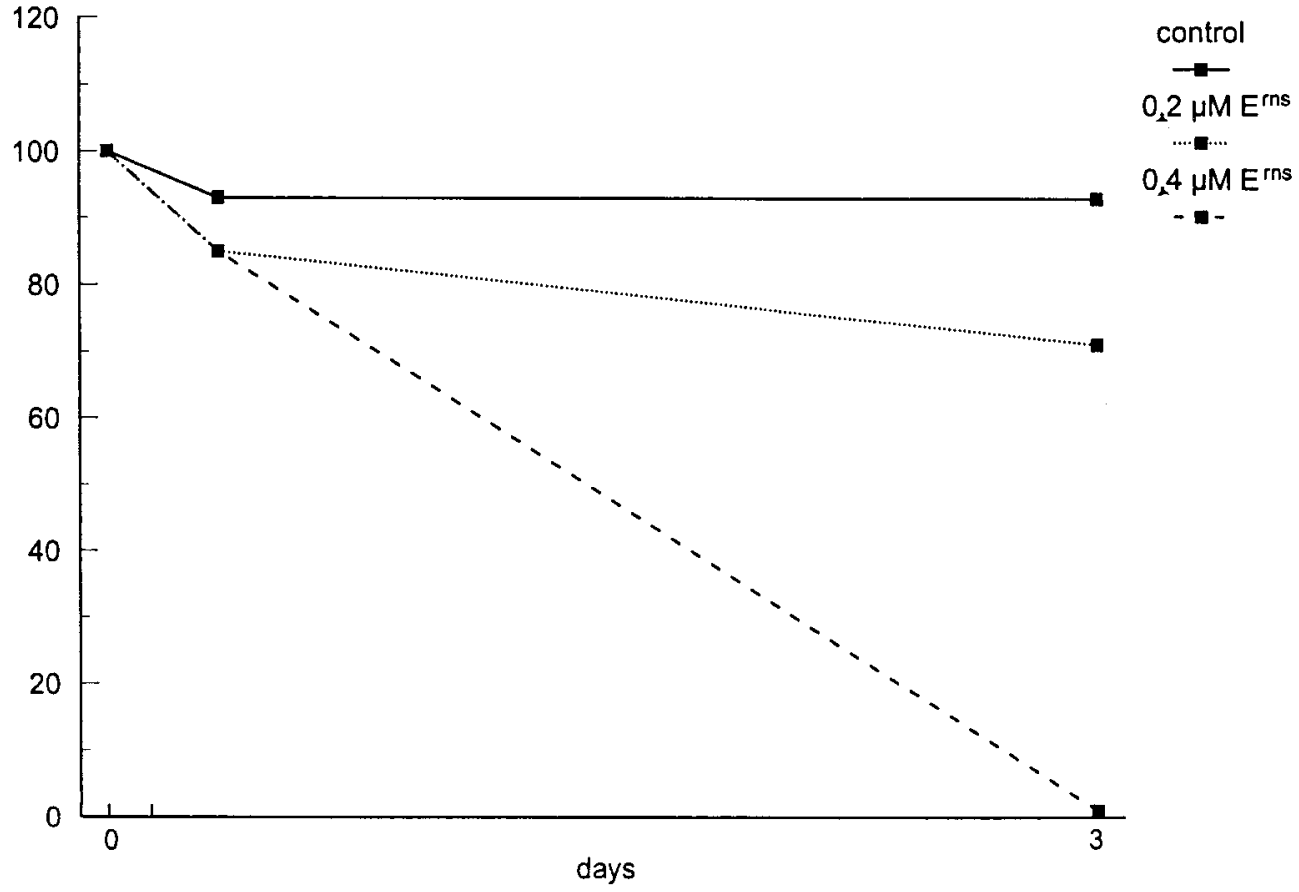

FIG. 2. Viability of lymphocytes as determined by nigrosine staining of stimulated lymphocytes after incubation with dilutions of $E^{\text {rns }}$.

cytes. Proliferation of lymphocytes of these species was also completely inhibited by $0.4 \mu \mathrm{M} \mathrm{E}^{\text {rns }}$. From these results, we conclude that $\mathrm{E}^{\text {rns }}$ is immunosuppressive for lymphocytes of species in which pestiviruses normally replicate as well as for lymphocytes of species in which pestiviruses normally do not replicate.

Cytotoxic action of $\mathbf{E}^{\text {rns }}$. The viability of bovine lymphocytes during the proliferation assay was studied by nigrosine staining of aliquots of cells. At the start of the assay, all wells contained more than $90 \%$ viable lymphocytes. After $4 \mathrm{~h}$ of incubation, the control wells contained $93 \%$ and the wells incubated with 0.2 and $0.4 \mu \mathrm{M} \mathrm{E}^{\text {rns }}$ contained $85 \%$ viable lymphocytes. After 3 days of incubation, the control wells still contained $93 \%$ and the wells incubated with $0.2 \mu \mathrm{M} \mathrm{E}^{\text {rns }}$ contained $71 \%$ viable lymphocytes. None of the lymphocytes in the wells incubated with $0.4 \mu \mathrm{M} \mathrm{E}^{\text {rns }}$ were viable at that time (Fig. 2). The nigrosine staining showed death of lymphocytes after incubation with $\mathrm{E}^{r n s}$, which suggested a cytotoxic effect of $\mathrm{E}^{\text {rns }}$.

The kinetics of lymphocyte protein synthesis was used to quantify cytotoxic effect. The effect of $\mathrm{E}^{r n s}$ on the protein synthesis of bovine lymphocytes was determined. A dose-dependent inhibition of protein synthesis that already became obvious after $4 \mathrm{~h}$ of incubation was observed. Incubation with $0.4 \mu \mathrm{M} \mathrm{E}^{\text {rns }}$ resulted after 8 and $24 \mathrm{~h}$ in decreases in protein synthesis of 41 and of $63 \%$, respectively. Concentrations of 0.1 and $0.025 \mu \mathrm{M}$ also resulted in a decrease in protein synthesis at all measured time points. A concentration of $0.006 \mu \mathrm{M} \mathrm{E}^{r n s}$ significantly enhanced instead of inhibited protein synthesis at all time points (Fig. 3).

$\mathrm{E}^{r n s}$-induced inhibition of protein synthesis was not specific for bovine lymphocytes. Protein synthesis of human, porcine, and ovine lymphocytes was measured after $8 \mathrm{~h}$ of incubation with $0.4 \mu \mathrm{M} \mathrm{E}^{r n s}$, and these results were similar to the results with the bovine lymphocytes. After investigation of the species specificity, we also studied the cell type specificity of the cyto- toxic effect of $\mathrm{E}^{r n s}$. We selected two epithelial cell lines in which pestiviruses normally replicate and measured protein synthesis after $8 \mathrm{~h}$ of incubation with $0.4 \mu \mathrm{M} \mathrm{E}^{r n s}$. In contrast to the results for the lymphocytes, we did not detect an obvious inhibition of protein synthesis in these cell types. In EBTr and SK6 cells, a decrease of $5 \%$ and an increase of $8 \%$, respectively, were measured. Incubation with cf 2 did not affect protein synthesis.

These results indicate that $\mathrm{E}^{\text {rns }}$ is cytotoxic for lymphocytes of different species and not for epithelial cells.

Apoptosis. Virus-induced apoptosis of infected cells has been described for several virus species, including pestiviruses (29). We showed that purified envelope glycoprotein $\mathrm{E}^{\text {rns }}$ induced apoptosis in bovine lymphocytes. Lymphocytes were incubated for $8 \mathrm{~h}$ with $\mathrm{E}^{\text {rns }}$ and then tested in the cell death detection ELISA. After incubation with $\mathrm{E}^{r n s}$, the amounts of mono- and oligonucleosomes in the lymphocytes, which indicate apoptosis of the cells, increased. The average enrichment factor after $E^{\text {rns }}$ incubation compared to that for incubation in regular cell culture medium was $3.9 \pm 1.2$. The control fraction cf2 did not induce apoptosis, as shown by an enrichment factor of $1.0 \pm 0.1$. Although it has been described that the cythopathic effect of pestiviruses is mediated by apoptosis (29), we did not detect apoptosis of EBTr cells after $\mathrm{E}^{r n s}$ incubation. The enrichment factor for mono- and oligonucleosomes in these cells was $1.1 \pm 0.02$.

\section{DISCUSSION}

In this study, we investigated the immunomodulatory properties of CSFV envelope glycoprotein $\mathrm{E}^{r n s}$ in vitro. We used the $\mathrm{E}^{r n s}$ produced in recombinant baculovirus-infected cells because it has the same characteristics as those of $\mathrm{E}^{\text {rns }}$ from CSFV-infected cells $(10,19) . \mathrm{E}^{\text {rns }}$ inhibited concanavalin Ainduced proliferation of bovine lymphocytes very efficiently. 


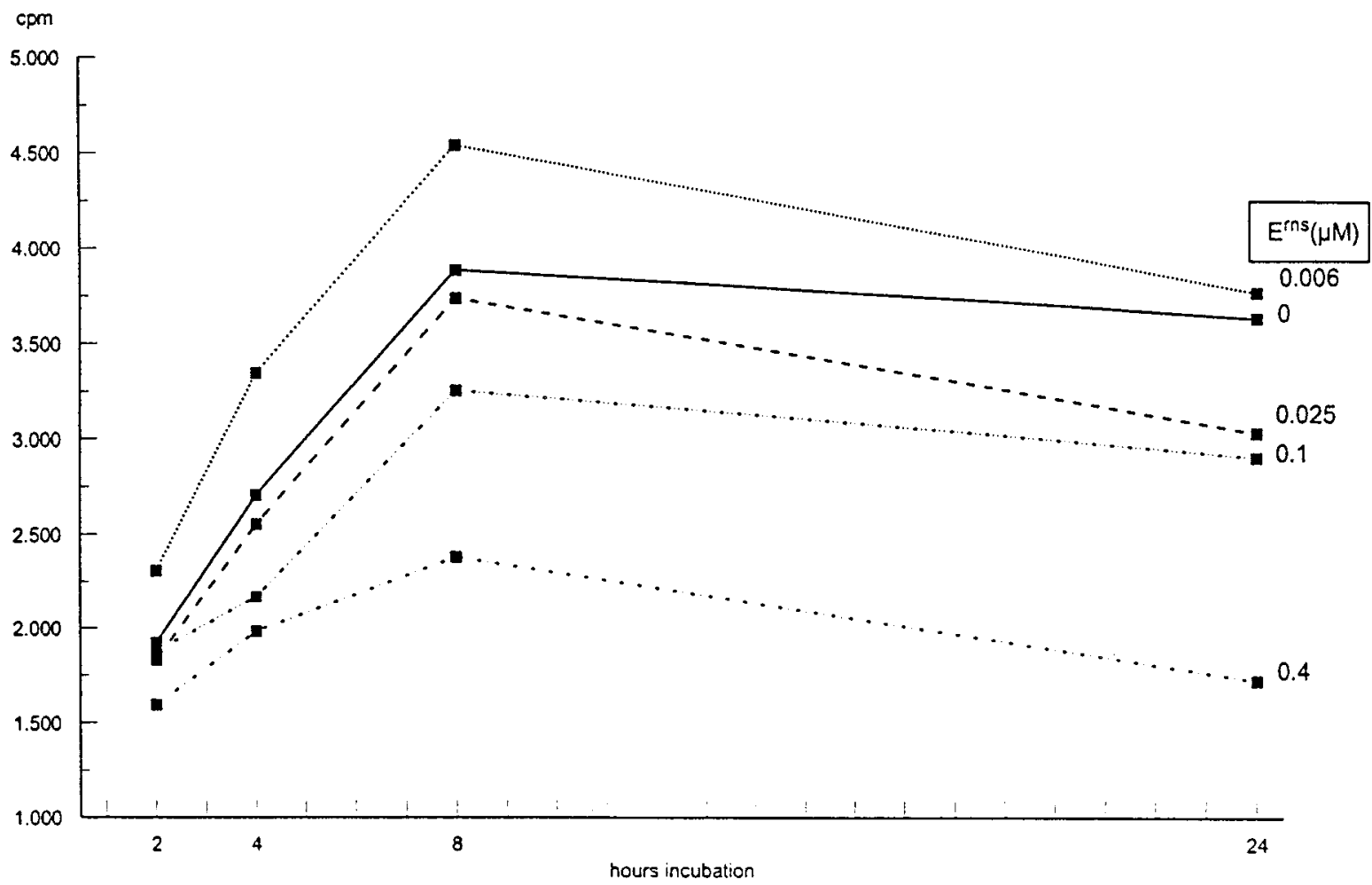

FIG. 3. Protein synthesis of bovine lymphocytes in the presence of specific dilutions of $\mathrm{E}^{\text {rns }}$. Dilutions of $\mathrm{E}^{\text {rns }}$ were based on the RNase activities of the fractions. The results are averages of triplicate samples (standard deviations, $<7 \%$ ).

The reduction of the $\left[{ }^{3} \mathrm{H}\right]$ thymidine incorporation was dependent on the concentration of $\mathrm{E}^{\text {rns }}$ in the lymphocyte cultures and could be partially blocked by a neutralizing MAb directed against $\mathrm{E}^{\text {rns }}$. Hulst (11) showed that $\mathrm{E}^{r n s}$ binds very strongly to the cell surfaces of bovine and porcine cells and that binding is probably irreversible. The binding of $\mathrm{E}^{\text {rns }}$ to MAb C5 is probably less strong and probably reversible. The stronger avidity of binding of $\mathrm{E}^{\text {rns }}$ for a cell surface receptor compared to that of MAb C5 might explain the only partial neutralization of the effect of $\mathrm{E}^{\text {rns }}$. Nigrosine staining of aliquots of stimulated lymphocytes, which indicates damage of the cell membrane, showed cell death after $\mathrm{E}^{\text {rns }}$ incubation. The percentage of dead lymphocytes was dependent on the concentration of $\mathrm{E}^{\text {rns }}$ and on the incubation time. To quantify the direct cytotoxic effect of $\mathrm{E}^{\text {rns }}$ on the lymphocytes, we performed the protein synthesis assay. After $4 \mathrm{~h}$ of incubation, the inhibition of the protein synthesis was significant for all studied concentrations of $\mathrm{E}^{\text {rns }}$, except for the lowest concentration tested. This concentration had a stimulatory effect. After $4 \mathrm{~h}$ of incubation, the nigrosine staining did not yet show a significant increase in the percentage of dead cells. Thus, $\mathrm{E}^{\text {rns }}$ induces a significant inhibition of the protein synthesis of lymphocytes before the cell membrane becomes permeable for nigrosine. Therefore, the cytotoxic effect of $\mathrm{E}^{\text {rns }}$ is probably not caused by direct damage of the cell membrane. The hypothesis that $E^{r n s}$ does not damage the cell membrane directly is further supported by the fact that a concentration of $0.006 \mu \mathrm{M} \mathrm{E}^{r n s}$ enhanced instead of inhibited protein synthesis.

Although CSFV infection is normally restricted to swine, no species specificity was detected for the cytotoxic effect of $E^{r n s}$ against lymphocytes. The levels of inhibition of the lymphocyte proliferation and of protein synthesis were comparable for all tested species, including humans. It was rather unexpected that this viral protein had such a strong immunosuppressive effect on human lymphocytes because pestiviruses normally do not infect humans. It may be speculated that viruses that induce immunosuppression in humans carry a protein with a function similar to that of $\mathrm{E}^{\text {rns }}$.

Pestiviruses preferably replicate in lymphoid tissue but also replicate in epithelial cells. We used SK6 and EBTr cells to investigate possible cytotoxic properties of $\mathrm{E}^{\text {rns }}$ against epithelial cells. No cytotoxic action was detected against the epithelial cells. Hence, the cytotoxic action of CSFV $E^{\text {rns }}$ in vitro is directed mainly against lymphocytes and is not restricted to cells of the natural host. Pestivirus envelope glycoprotein $\mathrm{E}^{\text {rns }}$ is defined as an RNase, and the catalytically important amino acid residues are highly conserved within the pestivirus genus $(10,19)$. The function of $E^{r n s}$, which is secreted from infected cells (18), in the viral life cycle is not yet clear. From other RNases, it is known that they can have, different noncatalytic biological actions, in addition to ribonucleolytic activity. They have been shown to be involved in antitumor, neurotoxic, helmintotoxic, and immunomodulatory processes $(4,14,16,23)$. A specific cytotoxic action of $\mathrm{E}^{\text {rns }}$ against lymphocytes is consistent with the pathogenesis of pestivirus infections. Acute virulent and persistent CSFV infections are characterized by severe leukopenia and immunosuppression $(21,25)$. In other pestivirus infections, immunosuppression is also a common phenomenon $(2,5,15)$.

Immune deficiency caused by apoptosis of lymphocytes has been described previously for a number of viruses such as human immunodeficiency virus (7), influenza viruses (8), and feline leukemia virus (17). Our results from the protein synthesis assay and nigrosine staining suggested that apoptosis in lymphocytes was induced by glycoprotein $\mathrm{E}^{\text {rns }}$ of CSFV. Indeed, in the cell death detection ELISA, it was clearly shown 
that $\mathrm{E}^{\text {rns }}$ induced apoptosis in lymphocytes. To our knowledge, this is the first time that selective apoptosis of lymphocytes induced by a purified viral glycoprotein has been described.

In our experiments, $E^{r n s}$ induced apoptosis in lymphocytes and not in epithelial cells, but Hulst (11) showed that $\mathrm{E}^{\text {rns }}$ is involved in virus-cell interaction of several epithelial cells. It interacts with the cell surfaces of PK15, SK6, fetal bovine epithelium, SF21, and CL626 cells, probably by binding to a common cell surface receptor. Since $\mathrm{E}^{r n s}$ only slightly inhibited protein synthesis of EBTr and even slightly enhanced protein synthesis of SK6 cells, we conclude that binding of $\mathrm{E}^{\text {rns }}$ to a cell surface does not necessarily give a cytotoxic effect or induce apoptosis. After binding of an RNase to a cell surface, several processes can occur. It can remain attached to the cell surface receptor without any effect on the cell. It can damage the cell membrane directly and cause cell necrosis (28). Activation of the cell surface receptor can possibly induce apoptosis (27). After binding, the RNase could also be internalized by membrane penetration or endocytosis. Then, degradation of RNA could induce apoptosis. Schneider et al. (19) showed a pronounced substrate specificity of $\mathrm{E}^{\text {rns }}$ for uridine and reduced activities for RNA substrates with high amounts of secondary structure. This suggests an RNA substrate specificity of $E^{\text {rns }}$ which could account for the cell-specific cytotoxicity. For other RNases, a substrate specificity has also been described (6). Selective internalization of $\mathrm{E}^{\text {rns }}$ by lymphoreticular cells or even by particular lymphocyte subsets might also explain selective induction of apoptosis.

Hence, our results raise the following question. Does $\mathrm{E}^{\text {rns }}$ induce apoptosis by activation of a cell surface receptor or is it internalized after binding?

Further studies are needed to elucidate the mechanism by which $\mathrm{E}^{r n s}$ acts on lymphocytes and to clarify the role of $\mathrm{E}^{\text {rns }}$ in infected animals. It may be hypothesized that $\mathrm{E}^{\text {rns }}$ is secreted in the blood of infected animals and consequently may affect lymphoid tissue throughout the body, as seen in acute infections with CSFV and in mucosal disease of cattle. Taken together, our results have shown that $\mathrm{E}^{r n s}$ inhibits lymphocyte proliferation and protein synthesis due to selective induction of apoptosis in the lymphocytes of several species. This effect suggests an important role for $\mathrm{E}^{\text {rns }}$ in the leukopenia and immunosuppression caused by pestivirus infections and might have implications for therapeutic use of $\mathrm{E}^{r n s}$ as an immunosuppressive agent.

\section{REFERENCES}

1. Bognár, K., and J. Mészáros. 1963. Experiences with lapinised hog cholera virus strain of decreased virulence. Acta Vet. Acad. Sci. Hung. 13:429-438.

2. Bolin, S. R., A. W. McClurkin, and M. F. Coria. 1985. Effects of bovine viral diarrhea virus on the percentages of circulating $\mathrm{B}$ and $\mathrm{T}$ lymphocytes in cattle. Am. J. Vet. Res. 46:884-886.

3. Collet, M. S., R. Larson, S. K. Belzer, and E. Petzel. 1988. Proteins encoded by bovine viral diarrhea virus: the genomic organisation of a pestivirus. Virology 165:200-208.

4. D'Alessio, G. 1993. New and cryptic biological messages from RNases. Trends Cell. Biol. 3:106-109.

5. Ellis, J. A., W. C. Davis, E. L. Belden, and D. L. Pratt. 1988. Flow cytofluorimetric analysis of lymphocyte subset alterations in cattle infected with bovine viral diarrhea virus. Vet. Pathol. 25:231-236.

6. Endo, Y., P. W. Hubert, and I. G. Wool. 1983. The ribonuclease activity of the cytotoxin $\alpha$-sarcin. J. Biol. Chem. 258:2662-2667.

7. Gougeon, M., and L. Montagnier. 1993. Apoptosis in AIDS. Science 260: $1269-1270$.

8. Hinshaw, V. S., C. W. Olsen, N. Dybdahl-Sissiko, and D. Evans. 1994 Apoptosis: a mechanism of killing by influenza A and B viruses. J. Virol. 68:3667-3673

9. Howard, C. R. 1992. Hepatitis C virus: a comparison with pestiviruses and other flaviviruses. In Proceedings of the Second Symposium on Pestiviruses, 1992. European Society for Veterinary Virology, Annecy, France.

10. Hulst, M. M., G. Himes, E. Newbigin, and R. J. M. Moormann. 1994 Glycoprotein E2 of classical swine fever virus: expression in insect cells and identification as a ribonuclease. Virology 200:558-565.

11. Hulst, M. M. Unpublished data.

12. Johnson, G. V., D. Wilson, L. Greenfield, and R. J. Youle. 1988. The role of the diphtheria toxin receptor in cytosol translation. J. Biol. Chem. 263:12951300 .

13. Kasza, L., J. A. Shadduck, and G. J. Christofinis. 1992. Establishment, vira susceptibility and biological characteristics of a swine kidney cell line SK-6. Res. Vet. Sci. 13:46-51.

14. Mañcheno, J. M., M. Gasset, M. Oñaderra, J. G. Gavilanes, and G. D'Alessio. 1994. Bovine seminal ribonuclease destabilizes negatively charged membranes. Biochem. Biophys. Res. Commun. 199:119-124.

15. Marshall, D. J., G. A. Perry, C. A. Kuszynski, K. M. Eskridge, and C. L. Kelling. 1994. Flow cytometric analysis of lymphocyte subsets in peripheral blood and lymphocyte tissues of gnotobiotic calves during primary acute postnatal infections of bovine viral diarrhea virus. Viral Immunol. 7:141-149.

16. Peterson, C. G. B., V. Skoog, and P. Venge. 1986. Human eosinophil cationic proteins (ECP and EPX) and their suppressive effects on lymphocyte proliferation. Immunobiology 171:1-13.

17. Rojko, J. L., R. M. Fulton, L. J. Rezanka, L. L. Williams, E. Copelan, C. M. Cheney, G. S. Reichel, J. C. Neil, L. E. Mathes, T. G. Fisher, and M. W. Cloyd. 1992. Lymphocytotoxic strains of feline leukemia virus induced apoptosis in feline T4-thymic lymphoma cells. J. Clin. Invest. 66:418-426.

18. Rümenapf, T., R. Stark, G. Meyers, and H.-J. Thiel. 1993. Structural proteins of hog cholera virus expressed by vaccinia virus: further characterization and induction of protective immunity. J. Virol. 67:589-597.

19. Schneider, R., G. Unger, R. Stark, E. Schneider-Scherzer, and H. J. Thiel. 1993. Identification of a structural glycoprotein of an RNA virus as a ribonuclease. Science 261:1169-1171.

20. Smith, G. H., J. K. Collins, J. Carman, and H. C. Minocha. 1988. Detection of cytopathic and non-cytopathic bovine viral diarrhea virus with an immunoperoxidase test. J. Virol. Methods 19:319-324.

21. Susa, M., M. König, A. Saalmüller, M. J. Reddehase, and H.-J. Thiel. 1992. Pathogenesis of classical swine fever: B-lymphocyte deficiency caused by hog cholera virus. J. Virol. 66:1171-1175.

22. Takamizawa, A., C. Mori, I. Fuke, S. Manabe, S. Murakami, J. Fujita, E. Onishi, T. Andoh, I. Yoshida, and H. Okayama. 1991. Structure and organistion of the hepatitis $\mathrm{C}$ virus genome isolated from human carriers. J. Virol. 65:1105-1113.

23. Tamburrini, M., G. Scala, C. Verde, M. R. Ruocco, S. Parente, and G. D'Alessio. 1990. Immunosuppressive activity of bovine seminal RNase on T-cell proliferation. Eur. J. Biochem. 190:145-148.

24. Thiel, H.-J., R. Stark, E. Weiland, T. Rümenapf, and G. Meyers. 1991. Hog cholera virus: molecular composition of virions of a pestivirus. J. Virol. 65:4705-4712

25. Van der Molen, E. J., and J. T. van Oirschot. 1981. Congenital persistent swine fever (hog cholera). I. Pathomorphological lesions in lymphoid tissues, kidney and adrenal. Zentralbl. Veterinaermed. Reihe B 28:89-101.

26. Wensvoort, G., E. P. de Kluyver, J. Boonstra, and C. Terpstra. 1989. Production and characterization of monoclonal antibodies against the "Chinese" strain of hog cholera vaccine virus. Ph.D. thesis. University of Utrecht, Utrecht, The Netherlands.

27. Wu, Y. N., S. M. Mikulski, W. Ardelt, S. M. Rybak, and R. J. Youle. 1993. A cytotoxic ribonuclease, study of the mechanism of onconase cytotoxicity. J. Biol. Chem. 268:10686-10693.

28. Young, J. D., C. G. B Peterson, P. Venge, and Z. A. Cohn. 1986. Mechanism of membrane damage mediated by human eosinophil cationic protein. Nature 321:613-616.

29. Zhang, G., S. Aldridge, M. C. Clarke, and J. W. McCauly. 1996. Cell death induced by bovine viral diarrhoea virus is mediated by apoptosis. J. Gen. Virol. 77:1677-1681. 